\title{
SOUTH OF HEIL, NORTH DAKOTA, POPULATION 24
}

Daniel Zinkand

The lichen-green rattlesnake lies in the sun on a road going somewhere out in nowhere ivory underbelly stained brown by tar seeping through sun-warmed asphalt.

Ya can't kill a rattler just by driving over it Ya just can't do it says Arndt clutching the F600 into third as we climb Haffner's Hill.

My aw-come-on face breaking through a wraith of cigarette smoke and August dust dies as Arndt yanks open the glovebox revealing rattles nestled by .22 shells and bounty-killed gopher tails. I finger an obsidian-colored rattle button for each year says Arndt.

When I see a snake Arndt says I back up a ways step on the gas 
and hit the brakes as I cross the snake.

Red-black flesh lies smeared

on the road

waiting for crows

coming from somewhere

out in nowhere

North Dakota. 